\title{
PENGANTAR BELAJAR STATISTIKA DASAR
}

\author{
ANDI ARSI \\ NIM: 18210038 \\ andiarsi291@gmail.com ac.id
}

\begin{abstract}
ABSTRAK
Statistik bisa digunakan untuk menyatakan kumpulan fakta, umunya berbentuk angka yang disusun dalam tabel atau diagram yang melukiskan atau menggambarkan suatu persoalan. Dengan kata lain, statistik bersifat sebagai data. Beda halnya dengan statistika yang merupakan su atu ilmu pengetahuan suatu ilmu pengetahuan yang berhubungan dengan data statistik dan fakta yang benar atau suatu kajian ilmu pengetahuan dengan teknik pengumpulan data, teknik pengolahan data, teknik analisis data, penarikan kesimpulan, dan pembuatan keb ijakan atau keputusan yang cukup kuat alasannya berdasarkan data dan fakta yang akurat. Jadi, statistika sebagai alat untuk enghitung atau menganalisis data. Landasan kerja statistik ada tiga yaitu: (a) variasi, didasarkan atas kenyataan bahwa seorang pen elitiselalu menghadapi persoalan dan gejala yang bermacam-macam baik dalam bentuk tingkatan maupun jenisnya; (b) reduksi, sebagian atau seluruh kejadian yang hendak diteliti (penelitian sampling); (c) generalisasi, sekalipun penelitian dilakukan terhadap sebagaian dan seluruh kejadian yang akan diteliti.
\end{abstract}

Kata kunci : statistik, statistika, penelitian ,data, dan fakta 


\section{PENDAHULUAN}

Bidang statistika dapat dianggap sebagai bahasa khusus yang juga didapat untuk berkomunikasi. Kekhususan statistika sebagai bahasa tidak berarti bahwa kita harus berkomunikasi secara berbeda, tetapi kekhususan dimaksud hanya sekedar untuk mendorong supaya cara kita berbicara atau menyajikan data lebih tepat dan akurat. Statistika sebagai bahasa juga memiliki aturan main sebagaimana bahasa-bahasa lainnya, statistika kata - kata dan gramatikanya. Namun demikian, statistika merupakan bahasa yang terbatas penggunaannya. Dengan statistika kita hanya mampu mebicarakan tentang ciri-ciri atau karakteristik tentang berbagai hal (benda atau sifat) yang kita amati. Sebelum statistika mampu berfungsi sebagai bahasa komunikasi yang baik, ia harus diberikan masukan terlebih dahulu berupa data mentah hasil obeservasi atau hasil penelitian (Suwarno, 2005).

statika bisa digunakan untuk ukuran sebagai wakil dari kelompok fakta mengenai nilai: nilai rata-rata mahasiswa, rerata produktivitas perusahaan, persentase keberhasilan belajarr, ramalan kemampuan mahasiswa memprediksi hasil produksi pertanian dan sebagainya. Untuk memperoleh sejumlah informasi yang menjelaskan masalah untuk ditarik kesimpulan yang benar, arus melalui beberapa proses, yaitu proses pengumpulan informasi, pengolahan informasi, dan proses penarikan kesimpulan. Kesemuanya itu memerlukan pengetahuan tersendiri yang disebut statsitika.

Sedangkan statistik dipakai untuk menyatakan kumpulan fakta, umumnya berbentuk angka yang disusun dalam tabel atau diagram yang melukiskan atau menggambarkan suatu persoalan. Dalam perkembangannya, untuk menyelesaikan suatu masalah dapat digunakan beberapa pendekatan antara lain statistika dalam arti sempit dan statsitika dalam arti luas (Hadi, 2014). Statistika dalam arti sempit (statistika deskriptif) adlaah statistika yang mendeskripsikan atau menggambarkan tentang data yang disajikan dalam bentuk tabel, diagram, pengukuran tendensi sentral, rata - rata hitung, rata rata ukur, dan rata-rata harmonik, pengukuran penempatan (median, kuartil, desil, dan persentil), pengukuran penyimpangan (range, rentangan antar kuartil, rentangan semi antar kuartil, simpangan rata - rata, simpangan baku, varians. Koefisien varians, dan angka 
baku), angka indeks serta mencari kuatnya hubungan dua variabel, melakukan peramalan (prediksi) dengan menggunakan analisis regresi linier, membuat perbandingan (komparatif). Tetapi dalam analisis korelasi, regresi maupun komparatif tid ak perlu menggunakan uji signifikansi karena tidak bermaksdu membuat generalisasi (bersifat umum) (Sudjana, 2004). Statistika dalam arti luas disebut juga dengan statistika inferensial atau statsitika induktif atau statsitika probabilitas yaitu suatu alat pengumpul data, pengolah data, menarik kesimpulan, membuat tindakan berdasarkan analisis data yang dikumpulkan atau statistika yang digunakan menganalisis data sampel dan hasilnya dimanfaatkan (generalisasi) untuk populasi (Sudjana, 2004). Dengan demikian, dapat dikatakan bahwa statistika adalah suatu ilmu pengetahuan yang berhubungan dengan data statistik dan fakta yang benar atau suatu kajian ilmu pengetahuan dengan teknik pengumpulan data, teknik pengolahan data, teknik analisis data, penarikan kesimpula n, dan pembuatan kebijakan atau keputusan yang cukup kuat alasannya berdasarkan data dan fakta yang akurat.

\section{PEMBAHASAN}

\section{Landasan Kerja Statistik ,}

Ada tiga jenis landasan landasan kerja statistik ,menurut Hadi (2014), meliputi :

a. Variasi. Didasarkan atas kenyataan bahwa seorang peneliti selalu menghadapi persoalan dan gejala yang bermacam-macam (variasi) baik dalam bentuk tingkatan dan jenisnya.

b. Reduksi. Hanya sebagian dan seluruh kejadia yang hendak diteliti (peneliti sampling). c. Generalisasi. Sekalipun penelitian dilak ukan terhadap sebagian dan seluruh kejadian yang hendak diteliti. Namun kesimpulan dan penelitian ini akan diperuntukkan bagi keseluruhan kejadian atau gejala yang hendak diambil.

\section{Karakteristik Pokok Statistik}

Ada beberapa karakteristik atau ciri-ciri pok ok statistik sebagai berikut, yaitu (Riduwan, 2015): 
a. Statistik bekerja dengan angka. Angka-angka ini dalam statistik mempunyai dua pengertian, yaitu (1) Angka statistik sebagai jumlah atau frekuensi dan angka statistik sebagai nilai dan harga. (2) Angka st atistik sebagai nilai mempunyai arti data kualitatif yang diwujudkan dalam angka.

b. Statistik bersifat objektif. Statistik bekerja dengan angka sehingga mempunyai sifat objektif, artinya angka statistik dapat digunakan sebagai alat pencari fakta, pengungkap kenyataan yang ada dan memberikan keterangan yang benar, kemudian menentukan kebijakan sesuai fakta dan temuannya yang diungkapkan apa adanya . c. Statistik bersifat universal (umum). Statistik tidak hanya digunakan dalam salah satu disiplin ilmu saja, tetapi dapat digunakan secara umum dalam berbagai bentuk disiplin ilmu pengetahuan.

\section{Manfaat dan Kegunaan Statistika}

Dalam perkembangan ilmu pengetahuan dan teknologi saat ini, bahwa ilmu statistika telah mempengaruhi hampir seluruh aspek kehidupan manusia. Selanjutnya, statistika dapat digunakan sebagai alat (Sudjana, 2004): Komunikasi, Deskripsi ,Regresi, Korelasi,Komparasi. Penggunaan statistika atau beberapa prosedur statistika harus didasarkan pada (a) sifat data yang tersedia, dan (b) masalah yang dihadapi.

\section{Variabel}

Dalam istilah bahasa statistika, objek yang bervariasi disebut variabel. Jadi, variabel adalah karakteristik yang dapat diamati dari sesuatu (objek), dan mampu memberikan bermacam-macam nilai atau beberapa kategori (Suwarno, 2005). Contohnya: berat adalah variasi, sebab semua o bjek beratnya tidak sama dan suatu objek dapat saja beratnya berubah - ubah dari waktu ke waktu. Umur, nilai kemajuan belajar, jenis kelamin, kecepatan, merupakan (a) ciri-ciri suatu objek (orang atau benda); (b) dapat diamati dan (c) berbeda dari satu obser vasi ke observasi lainnya; disebut variabel. Dan variabel adalah data mentah untuk statistika. Variabel yang sering digunakan dalam penelitian, yaitu variabel: (a) bebas ( independent ); (b) terikat (dependent ); (c) moderator; (d) intervening; dan (e) kontrol(Riduwan, 2015). 


\section{. 5. Skala}

Apabila data dari suatu varaibel akan dipergunakan dalam analisis statsitika maka data itu harus tersusun dengan cara sistematis (teratur). Kita perlu mendefinisikan setiap variabel secara operasional, artinya harus mampu menjelask an dengan langkah - langkah yang sesuai dengan kemungkinan-kemungkinan untuk mengubah nila-nilai yang ada di dalamnya (Sudjana, 2004). Definisi seperti itu memerlukan gambaran yang jelas dari ciri-ciri atau sifat-sifat yang akan diamati dan memerlukan spesif ikasi dari kategori yang variasinya perlu dicatat. Para ahli statistika menyebut prosedur pendefinisian variabel secara operasional tersebut dengan istilah scaling dan hasilnya disebut scale atau skala (Riduwan dan Sunarto, 2013). Dapat dikatakan bahwa ham pir semua skala ditentukan oleh kebiasaan yang berlaku. Umur anak setahun berarti dihitung dari ulang tahunnya yang pertama setelah lahir. Dan setelah hari ulang tahunnya yang kedua, ia berumur dua tahun dan seterusnya. Jadi, seseorang yang menyatakan beru mur 15 tahun, paling tidak ia telah 15 tahun dan mungkin lebih 2 hari atau mungkin 340 hari. Jadi, untuk umur telah tersedia patokan atau ukuran baku untuk menyusun skalanya. Perlu dicatat bahwa skala yang digunakan untuk mencatat suatu variabel bukan bagi an dari variabel tetapi merupakan bagian dari definisi operasionalnya. Meskipun banyak variabel yang telah mempunyai nilai atau kategori (menurut kebiasaan) yang baku, akan tetapi di dalam ilmu sosial biasanya peneliti sendiri yangmenentukan. Variabel kel as sosial (termasuk pendidikan) kadang - kadang diskalakan menjadi kaya-sedang-miskin.

\section{Paradigma Penelitian dan Pendekatan Penelitian}

Telaah penting dalam kaitan kajian yang terkait dengan persoalan paradigma penelitian adalah secara substantif paradigma penelit ian berarti suatu cara pandang tentang bagaimana suatu penelitian itu idealnya harus dilakukan peneliti.

Secara terminologis, paradigma yang dikenal dalam penelitian utamanya mencakup empat paradigma. Keempat paradigma yang dimaksud terdiri dari positivist ik, kritis, kontruktivis dan participatory (Imron, 2013). Paradigma positivistik merupakan paradigma paling awal dan karenanya ia dikenal juga dengan konsep paradigma klasik. Dalam kaitan hubungan proses dan hasil penelitian dalam suatu penelitian, maka da lam paradigma ini dianalogikan dengan simbol dan deskripsi 
sebagai. Analogi dari ilustrasi tersebut adalah peneliti (P) melihat objek (O) penelitian dengan $\mathrm{H}$ sebagai hasil penelitian dari sudut pandang $\mathrm{P}$.

Selanjutnya, berkaitan dengan cara da lam melaporkan data penelitian, maka paradigma ini melakukannya dengan cara menggunakan bahasa formal dan standar dan menggunakan teknik "menceritakan kembali film yang kita tonton".

Kemudian menyangkut paradigma kritikal. Dalam kaitan hubungan proses dan hasil penelitian dalam suatu penelitian, maka dalam paradigma ini dianalogikan dengan simbol dan deskripsi sebagai . Analogi dari ilustrasi tersebut adalah peneliti $(\mathrm{P})$ melihat objek (O) via teori kritis dengan $\mathrm{H}$ sebagai hasil penelitian dari sudut pandang $\mathrm{O}$.

Lalu berkaitan dengan cara dalam melaporkan data penelitian, maka paradigma ini melakukannya dengan cara menggunakan bahasa informal dan advokatif serta dengan menggunakan teknik "menggugah kesadaran pembicara dari apa yang dirasakan korb an".

Menyangkut paradigma konstruktivis, maka dalam kaitan proses dan hasil penelitian dalam suatu penelitian, maka dalam hubungan paradigma ini dianalogikan dengan simbol dan deskripsi. Analogi dari ilustrasi tersebut adalah peneliti $(P)$ mel ihat objek $(O)$ dari perspektif $\mathrm{O}$ dengan hasil $(\mathrm{H})$ dari sudut pandang objek (O).

Kemudian terkait dengan cara dalam melaporkan data penelitian, maka paradigma ini melakukannya dengan cara menggunakan bahasa informal dan indegenous. Dan dengan menggunakan te knik "penyambung lidah pihak yang diteliti atau subjek penelitian". Terakhir yaitu paradigma participatory. Dalam kaitan hubungan proses dan hasil penelitian dalam suatu penelitian, maka dalam paradigma ini dianalogikan dengan simbol dan deskripsi. Analogi dari ilustrasi tersebut adalah peneliti (P) melihat objek (O) dari perspektif objek dan peneliti dengan hasil $(\mathrm{H})$ dari sudut pandang bersama objek dan peneliti.

Kemudian, terkait dengan cara dalam melaporkan data penelitian, maka paradigma ini melakukannya dengan cara menggunakan bahasa aksi; dan menggunakan teknik "konsultan" yang menunjukkan tindakan praktis apa yang mesti dilakukan. 
Gambaran mengenai proses penelitian pada masing-masing paradigmatadi, selanjutnya dapat dilihat dari tabel berikut.

Tabel 1. Paradigma Penelitian dan Pelaksanaan Penelitian (Imron, 2013)

\begin{tabular}{|c|c|c|c|c|}
\hline & $\begin{array}{l}\text { Klasifikasi/positivist } \\
\text { ik }\end{array}$ & kritis & $\begin{array}{l}\text { Konstruktivisi } \\
\mathrm{s}\end{array}$ & Participatory \\
\hline $\begin{array}{l}\text { Hubungan } \\
\text { proses } \\
\text { dan hasil } \\
\text { penelitian }\end{array}$ & $\begin{array}{l}\text { P-.O- H } \\
\text { Penelitian(p)meliha } \\
\text { t objek(o)penelitan } \\
\text { dengan H sebagai } \\
\text { hasil penelitian dari } \\
\text { sudut pandang }(p) .\end{array}$ & $\begin{array}{l}\mathrm{P}-\mathrm{O}+\text { teori kritis - } \\
\mathrm{H} \\
\text { Penelitian(p)melih } \\
\text { at objek(o)via teori } \\
\text { kiritis dengan } \mathrm{H} \\
\text { sebagai hasil } \\
\text { penelitian } \mathrm{O} \text {. }\end{array}$ & $\begin{array}{l}\text { P- } \\
\text { O+Empatif-H } \\
\text { penelitian(p) } \\
\text { melihat } \\
\text { objek(o) dari } \\
\text { perspektif O } \\
\text { dengan } \\
\text { hasil(H)dari } \\
\text { sudut } \\
\text { pandang } \\
\text { objek(O). }\end{array}$ & $\begin{array}{l}\text { P- O+ Interaktif - } \\
\mathrm{H} \\
\text { Penelitian(p)melih } \\
\text { at objek(O)Dari } \\
\text { prespektif objek } \\
\text { dan penelitian } \\
\text { dengan hasil (H) } \\
\text { Dari sudut } \\
\text { pandangbersama } \\
\text { objek (O) Dan } \\
\text { penelitian(p). }\end{array}$ \\
\hline $\begin{array}{l}\text { Cara } \\
\text { melaporka } \\
\text { n data }\end{array}$ & $\begin{array}{l}\text { Menggunakan } \\
\text { bahasa formal dan } \\
\text { standar }\end{array}$ & $\begin{array}{l}\text { Menggunakan } \\
\text { bahasa informal } \\
\text { dan advokatif }\end{array}$ & $\begin{array}{l}\text { Menggunaka } \\
\text { n bahasa } \\
\text { informal dan } \\
\text { indegenous }\end{array}$ & $\begin{array}{l}\text { Menggunakan } \\
\text { bahasa aksi }\end{array}$ \\
\hline
\end{tabular}

Dengan gambaran pandangan berfikir pada sejumlah paradigma penelitian sebelumnya, hal ini menunjukkan adanya konsekuensi pada jenis data yang akan diperoleh melalui penelitian. Ko nsekuensinya berupa jenis data yang diperoleh, yaitu jenis kuantitatif dan kualitatif. Data kunatitatif muncul dalam wujuh angka-angka, sementara data kualitatif muncul dalam wujud bahasa verbal dan non verbal. Konsekuensi ini muncul karena berhubungan den gan cara memperolehnya dalam proses penelitian. 


\section{KESI IMPULA N}

Dunia penelitian atau riset, di manapun dilakukan, bukan saja telah mendapat manfaat yang baik statistika tetapi sering harus menggunakannya. Untuk mengetahui apakah cara yang baru ditemukan lebih baik daripada cara yang lama, ataupun penelitian yang dilakukan di lapangan, perlu diadakan penilaian dengan statistika. Apakah model untuk sesuatu hal dapat kita gunakan atau tidak, perlu diteliti dengan menggunakan teori statistika. Statistika juga telah cukup mampu untuk menentukan apakah faktor yang satu dipengaruhi atau mempengaruhi faktor lainnya. Hal ini menunjukkan bahwa statistika sangat diperlukan dalam bidang pengetahuan guna mengetahui tingkat kebaikan dari hal yang diteliti.

\section{DAFTAR PUSTAKA}

Arsyam, M.(2020). MANAJEMEN PENDIDIKAN ISLAM: Herianto,H.(2020)Teknik Menulis Artikel Konseptual.HERIANTO ,H.(2020)telah kurikulum 2013: hasi revisi 2018.jusmiana A, \& HERIANTO ,H.(2020) Suplemen materi statistika terapan dalam ilmu kesehatan.sapada,A,O,\& Arsyam,,M.(2020)IImu pengetahuan dan teknologi menurut pandangan islam"Skala Pengukuran dalam Penelitian . Bandung: CV Alfabeta. Sudjana (2004). Metoda Statistika .Bandung: PT. Tarsito. Suwarno, Bambang. (2005). Pengantar Aplikasi Statistika . Bandung: PPs Universitas Pendidikan Indonesia. 